\title{
MODEL PENGELOLAAN SUMBERDAYA MANUSIA BERBASIS KOMPETENSI ERA INDUSTRI 4.0
}

COMPETENCY-BASED HUMAN RESOURCE MANAGEMENT MODEL IN THE INDUSTRIAL ERA 4.0

\author{
Nopi Hidayat $^{*}$, , Musa Hubeis ${ }^{* *}$, Anggraini Sukmawati**), dan Eriyatno ${ }^{*}$ \\ ${ }^{*}$ Sekolah Bisnis, IPB University \\ Jl. Raya Pajajaran, Bogor 16151, Indonesia \\ ${ }^{* *}$ Departemen Manajemen, Fakultas Ekonomi dan Manajemen, IPB University \\ Jl. Agatis Kampus IPB Dramaga, Bogor 16680, Indonesia
}

\begin{abstract}
The symptoms caused by the existence of industry 4.0 indirectly encourage or force the organization to prioritize human resource management (Human Resource Management) so that it can last a long time and develop more advanced. This research was conducted to build a design model of competency-based human resource management across generations of the industrial era 4.0 using a soft system method. Generational differences that have been considered problems, are seen differently when the differences in the characteristics of the three generations (baby boomers, $X$ and $Y$ ) are used as opportunities and complementary strengths in the challenges of the industrial world 4.0. In the current competency-based human resource management there are some gaps. The competency-based human resource management model across generations of 4.0 provides strategic steps taken in managing human resources.
\end{abstract}

Keywords: generation, human resource management model, industry 4.0, soft sytem method

\begin{abstract}
Abstrak: Gejala-gejala yang diakibatkan eksistensi industri 4.0 secara tidak langsung mendorong atau memaksa organisasi untuk mengutamakan pengelolaan sumber daya manusia (Human Resource Management) agar bisa bertahan lama dan berkembang lebih maju. Penelitian ini dilakukan untuk membangun rancangan model pengelolaan sumberdaya manusia berbasis kompetensi lintas generasi era industri 4.0 dengan menggunakan soft sytem method. Perbedaan generasi yang selama ini dianggap permasalahan, dipandang berbeda ketika bedaan karakteristik ketiga generasi (baby boomer, X dan Y) ini dijadikan peluang dan kekuatan yang saling melengkapi dalam tantangan dunia industri 4.0. Pada pengelolaan sumberdaya manusia berbasis kompetensi yang ada saat ini ditemukan beberapa kesenjangan. Model Pengelolaan sumberdaya manusia berbasis kompetensi lintas generasi era 4.0 memberikan langkah-langkah strategik yang dilakukan dalam mengelola sumberdaya manusia.
\end{abstract}

Kata kunci: generasi, industri 4.0, model pengelolaan sumber daya manusia, soft sytem method

${ }^{1}$ Corresponding author:

Email: hidayatnopi7@gmail.com 


\section{PENDAHULUAN}

Dunia global sedang berada pada era revolusi industri 4.0 yang menuntut umat manusia harus serba cepat dalam segala hal dengan memaksimalkan penggunaan alat-alat teknologi-informasi yang serba canggih. Aryal et al. (2018) menjelaskan bahwa seiring dengan meningkatnya perhatian penelitian pada Internet of Things (IoT) dan Cyber-Physical System (CPS) dalam beberapa tahun terakhir industri, pemerintah dan masyarakat pada umumnya telah memperhatikan kecenderungan organisasi 4.0 dan memaksimalkan apa yang kemudian bisauntuk mendatangkanmanfaatsecara profit. Tentunya ini berbeda dengan model atau sistem dalam 3 (tiga) fase industri sebelumnya, mekanisasi (industri 1.0 di abad ke-18), mass production (industri 2.0 di awal abad 20-an), dan automation (industri 3.0 di 1970-an).

Diamandis dan Kolter (2015) telah meyakini bahwa rahasia untuk memberi dampak positif bagi kehidupan jutaan orang adalah memahami dan menginternalkan siklus pertumbuhan teknologi digital. Siklus pertumbuhan ini terjadi dalam enam langkah kunci, yang dinamakan sebagai Six Ds of Exponentials: digitization, deception, disruption, demonetization, dematerialization, and democratization. Tentunya hal ini berimplikasi pada garis-garis industri menjadi kabur; persaingan muncul dari sumber-sumber non-tradisional yang sering mencari keuntungan di luar produk itu sendiri (kedekatan dan pengetahuan pelanggan, akses ke tingkat data tingkat pesanan yang lebih tinggi, dan lain-lain.). Pada akhirnya, pemain kecil yang lebih gesit dan mahir memanfaatkan berbagai teknologi eksponensial dapat meningkatkan, mengungguli, dan mengalahkan industri yang lebih besar (Deloitte, 2018).

Bagian terintegrasi dari tantangan dan peluang di era industri 4.0 bagi organisasi adalah adanya perbedaan generasi (gapgeneration) dengan disparitas kemampuan tiga golongan angkatan kerja antara generasi baby boomers, generasi X (baby busters) dan generasi Y (millennials). Tapscott (1998) membagi generasi berdasarkan kesamaan rentang waktu kelahiran dan kesamaan kejadian-kejadian historis Baby Boomers (1946-1964), G-X (1965-1975), dan G-Y (19762000). Pemahaman dasar mengenai pengelompokan generasi yakni adanya premis bahwa generasi adalah sekelompok individu yang dipengaruhi oleh kejadiankejadian bersejarah dan fenomena budaya yang terjadi dan dialami pada fase kehidupan mereka (Nobel dan Schewe 2003; Twenge 2000), dan kejadian serta fenomena tersebut menyebabkan terbentuknya ingatan secara kolektif yang berdampak dalam kehidupan manusia (Dencker et al. 2008). Jadi kejadian historis, sosial, dan efek budaya bersama dengan faktor-faktor lain ini akan berpengaruh terhadap terbentuknya perilaku, nilai, dan kepribadian seseorang (Caspi dan Roberts 2001; Caspi et al. 2005).

Penataan sumber daya manusia merupakan hal penting yang perlu diperhatikan oleh manajemen untuk menjaga serta mengembangkan organisasi di era industri 4.0. Gejala-gejala yang diakibatkan eksistensi industri 4.0 secara tidak langsung mendorong atau memaksa organisasi untuk mengutamakan pengelolaan sumber daya manusia (Human Resource Management) agar bisa bertahan lama dan berkembang lebih maju. Tujuan Human Resource Management (HRM) adalah untuk menarik, memotivasi, dan mempertahankan karyawan dalam peran mereka, tetapi fungsi administratif yang terkait dengan bidang ini selalu rumit dan padat karya. Banyak pendekatan yang dapat digunakan oleh manajemen guna mengembangkan human resource yang dimiliki. Al-Azzeh dan Nuaimi (2015) menjelaskan bahwa sumber daya manusia merupakan konsep yang diambil dari persepktif strategis, dimana konsep ini bertujuan untuk membuat organisasi sustainable dengan membentuk kompetensi sumber daya manusia yang unggul. Khanna dan Gupta (2014) pendekatan competency based human resource management (CB-HRM) adalah suatu metode yang tepat dalam mengembangkan organisasi serta kompetensi hal ini disebabkan variasi aktifitas (kegiatan) yang dilakukan saling terintegrasi satu sama lainnya.

Pada bisnis yang sangat ketat dalam persaingan, saat ini dituntut kemampuan kompetitif yang berkelanjutan. Ashkezari dan Aeen (2012) faktor kemampuan kompetitif yang berkelanjutan dinilai penting untuk mencapai organisasi yang terus berkembang dan bertahan lama. Ozcelik dan Ferman (2006) menjelaskan saat ini pandangan lebih mengarah terhadap kemampuan organisasi atau dalam arti lain sumber daya pendukung didalamnya, hal ini disebabkan modal serta teknologi semakin tersedia bagi hampir semua individu. Qiao dan Wang (2009) kesadaran yang dirasakan oleh organisasi selanjutnya diimplementasikan dengan terus mengembangkan basis kompetensi manusia atau pegawai yang dimiliki. 
Era Industri 4.0 memberikan tekanan besar bagi manajemen dalam mengelola sumber daya yang dimiliki serta pengelolaan dimasa depan. Pada era ini secara umum setiap manajemen juga dihadapkan dengan tantangan untuk mensinergikan antara teknologi dengan berbagai pemangku kepentingan organisasi. Kavanagh et al. (2015) menjelaskan bahwa sistem yang digunakan oleh manajemen saat ini perlu meningkatkan kompetensi manusia dalam rangka menerapkan sistem yang mampu memperoleh, menyimpan, memanipulasi, menganalisis, mengambil dan mendistribusikan untuk efektifitas kinerja organisasi. Stone et al. (2015) menerangkan bahwa perusahaan memerlukan implementasi nyata dalam mengitegrasikan kemampuan kompetensi pegawai dengan teknologi yang digunakan dalam aktifitas rekrutmen, seleksi, pelatihan dan kompensasi agar mampu bersaing.

Dalam penelitian ini, BPJS Kesehatan menjadi Case study dinilai sangat relevan dengan tuntutan industri 4.0, Kondisi ini disebabkan BPJS Kesehatan telah beralih dari cara kerja konvensional ke modern pada internal proses bisnis maupun pada pelayanan peserta serta provider kerjasamanya. Hal ini memberikan dampak pada kebutuhan kompetensi pegawai yang sesuai tuntutan organisasi industri era 4.0, jumlah pegawai tetap. BPJS Kesehatan tahun 2018 didukung oleh 6958 orang pegawai dengan 13 Kedeputian Wilayah, 127 Kantor Cabang, dan 388 kantor Kabupaten/Kota yang tersebar di seluruh Indonesia. Adapun jumlah peserta JKN-KIS per 31 Desember 2019 sudah mencapai 215 juta jiwa. Sejak tahun 2017 BPJS Kesehatan tidak lagi menambah kantor cabang maupun menambah pegawai.

Tenaga kerja yang mendukung BPJS Kesehatan melingkupi tiga generasi yaitu G-Baby Boomers, G-X dan G-Y, yang pastinya memiliki perbedaan kapasitas dan karakter kerja masing-masing. BPJS Kesehatan mempercayai bahwa dalam rangka mendukung misi pemerintah agar terus berjalan, BPJS Kesehatan membutuhkan human capital yang memiliki kemampuan yang handal dan profesional untuk menjaga dan membangun organisasi ke depan agar lebih progresif. Apalagi jumlah peserta BPJS Kesehatan dari tahun ke tahun semakin meningkat, yang mana per 1 Januari 2019 sudah mencapai 215.784.340 jiwa. Artinya, tugas dan tanggungjawab pelayanan juga harus ditingkatkan.
Dalam lima tahun mendatang, Gencarnya tuntutan industri 4.0, diprediksikan sebanyak 35\% jenis pekerjaan akan hilang, bahkan dalam 10 tahun yang akan datang jenis pekerjaan yang akan terhapus bertambah menjadi 75\%, (Prabowo, 2018). Hal ini disebabkan pekerjaan yang diperankan oleh manusia setahap demi setahap digantikan dengan system digital (Rosyadi, 2018). BPJS Kesehatan sudah tidak melakukan rekuitmen dan telah mempertimbangkan banyak proses serta beban kerja diambil alih oleh Teknologi Informasi Komunikasi (TIK) yang terus berkembang yang mengalihkan banyak proses yang resource based menjadi Information, Communication and Technology (ICT) based. Artinya, terdapat beberapa jenis pekerjaan diproyeksikan akan hilang di BPJS Kesehatan sehingga pengelolaan SDM dalam menggunakan alat-alat teknologi canggih mendesak digalakkan dalam sistem kerja institusi ini agar mampu menjadi organisasi 4.0 (Media Eksternal BPJS Kesehatan, 2017).

Permasalahan yang kompleks, tidak menentu, dan dinamis yang dihadapi di era industri 4.0 termasuk adanya perbedaan generasi membutuhkan strategi untuk mengelola SDM agar memiliki kompetensi mumpuni agar dapat menjadikan BPJS Kesehatan menjadi organisasi 4.0 pada lintas generasi. Oleh karena itu, dalam penelitian ini, dibutuhkan pendekatan Soft Systems Methodology (SSM) untuk mengetahui model strategi pengelolaan kompetensi yang paling berpengaruh pada pengelolaan SDM pada lintas generasi di organisasi 4.0.

\section{METODE PENELITIAN}

Penelitian ini dilakukan untuk membangun rancangan model dan merumuskan prioritas strategi pengelolaan sumberdaya manusia berbasis kompetensi lintas generasi era industri 4.0 dengan menggunakan mix method (kualitatif dan kuantitatif). Penelitian ini dilakukan terhadap pengelolaan pegawai di BPJS Kesehatan. Dalam penelitian ini instansi-instansi yang memiliki keterkaitan yaitu: Direktorat Perluasan dan Pelayanan Peserta BPJS Kesehatan, Direktorat Teknologi Informasi BPJS Kesehatan, Direktorat SDM dan Umum BPJS Kesehatan, Direktorat Perencanaan, Pengembangan dan Manajemen Risiko BPJS Kesehatan, Kementerian Kesehatan, Provider kerjasama BPJS Kesehatan, Akademisi dan Praktisi dibidang Sumber Daya Manusia. Data diperoleh dengan menggunakan metode wawancara secara mendalam (in-depth interview), Focus Group Discussion (FGD) dan studi literatur sumber relevan dan terpercaya. 
Jenis dan sumber data yang digunakan di dalam penelitian ini terdiri 1) Data primer, diperoleh langsung dari responden melalui wawancara mendalam (indepth interview) pada beberapa pakar yang meliputi pejabat berwenang di Direktorat Perluasan dan Pelayanan Peserta BPJS Kesehatan, Direktorat Teknologi Informasi BPJS Kesehatan, Direktorat SDM dan Umum BPJS Kesehatan, Direktorat Perencanaan, Pengembangan dan Manajemen Risiko BPJS Kesehatan, Kementerian Kesehatan, fasilitas kesehatan kerjasama BPJS Kesehatan, Akademisi dan Praktisi dibidang Sumber Daya Manusia. 2) Data sekunder, diperoleh dalam bentuk arsip, data internal terkait jumlah pegawai (SDM), daftar kompetensi diambil dari buku kamus dan model kompetensi BPJS Kesehatan yang diterbitkan di 2017, jurnal, buku, informasi dari internet yang relevan dan kredibel untuk menguatkan penelitian.

Soft System Methodology (SSM) pertama kali dikembangkan oleh Checkland and kerabatnya di Lancaester University dan digunakan sebagai sebuah metode dalam sistem pembelajaran dengan fitur-fitur tertentu dan intervensi yang tinggi oleh manusia. Salah satu kasus utama dimana sistem ini dipergunakan adalah sistem pelayanan kesehatan dan ini dikerjakan oleh Checkland secara langsung. SSM berpusat pada dekomposisi, penjelasan dan sintesa dari sebuah permasalahan, sedangkan menurut William (2005). sistem ini merupakan sebuah alat yang dapat digunakan untuk pemodelan, pembelajaran dan pengembangan (Zarei et al. 2014).

Menurut Davis dan Girou (1996) menjelaskan bahwa mengenai analisis informasi tentang persepsi manusia yang tidak tersusun dapat menggunakan SSM. SSM telah berevolusi dari hard-system thinking tradisional dimana memandang realitas sebagai sesuatu yang dipertimbangkan dan penyelidikan yang sistematis menjadi soft-system thinking dimana realitas menjadi problematis namun penyelidikan tetap sistematis. Pendekatan ini sangat berguna dalam menganalisa sudut pandang stakeholders pada berbagai macam bidang seperti manajemen banjir, ketersediaan air, dan identifkasi poin penghambat. Teknik pemecahan masalah dan sebuah analisis terkait masalah di dunia nyata, struktur informasi SSM menjadi informasi yang tidak beraturan menjadi sesuatu yang sistematis (Bosch et al. 2007). Adapun kerangka pemikiran pada Gambar 1.
Pengelolaan sumber daya berbasis kompetensi merupakan hal penting yang diperlukan dalam rangka mempercepat pertumbuhan dan pencapaian tujuan organisasi. Para ahli telah menyatakan bahwa terdapat enam komponen penting yang mampu memengaruhi pengelolaan sumber daya manusia berbasis kompetensi yaitu performance management, recruitment, career \& succession plan, reward, selection, dan training \& development. Saat ini diketahui bahwa permasalahan pada setiap manajemen, khususnya BPJS Kesehatan terkait dengan komposisi pegawai dari beberapa generasi yang dimiliki, kondisi ini perlu dikelola akibat adanya perbedaan pandangan, nilai, dan cara bekerja. BPJS Kesehatan telah berupaya mengikuti perubahan teknologi akibat adanya dorongan Industri 4.0 , pentingnya merespons perubahan dalam rangka bertahan dan keberlanjutan organisasi. Checkland (1999) menjelaskan bahwa dalam sebuah sistem sangat diperlukan untuk mengetahui aktor dan faktor penting yang memberikan pengaruh terhadap berjalannya suatu proses. Saat ini BPJS Kesehatan memerlukan model yang mampu mendorong pembentukan prioritas strategi terkait pengelolaan sumber daya manusia berbasis kompetensi di tengah perbedaan generasi dan Industri 4.0.

\section{HASIL}

Penelitian bersifat studi kasus dengan research policy menggunakan metode soft sytem methodology. Penggunaan metode tersebut ditujukan untuk menemukan model serta cara terbaik dalam menghadapi permasalah pengembangan organisasi terkait lintas generasi. Checkland dan Poulter (2006) menjelaskan metode SSM ditujukan untuk mendeskripsikan situasi melalui role, norms dan value. Para pelaksana memberikan pandangan terhadap peran, nilai dan norma yang terjadi pada suatu organisasi, kelompok atau grup. Pendapat digali melalui pertemuan, wawancara, diskusi, studi literature, focus group discussion. Aktifitas tersebut kembali dilakukan pada tahap soft sytem methodology lainnya dalam rangka melakukan face validity atau mengkonfirmasi dari tiap prosesnya antara lain rich picture, root definition, purposive activity model dan pembandingan dengan dunia nyata (Sarantopolus, 2017). 


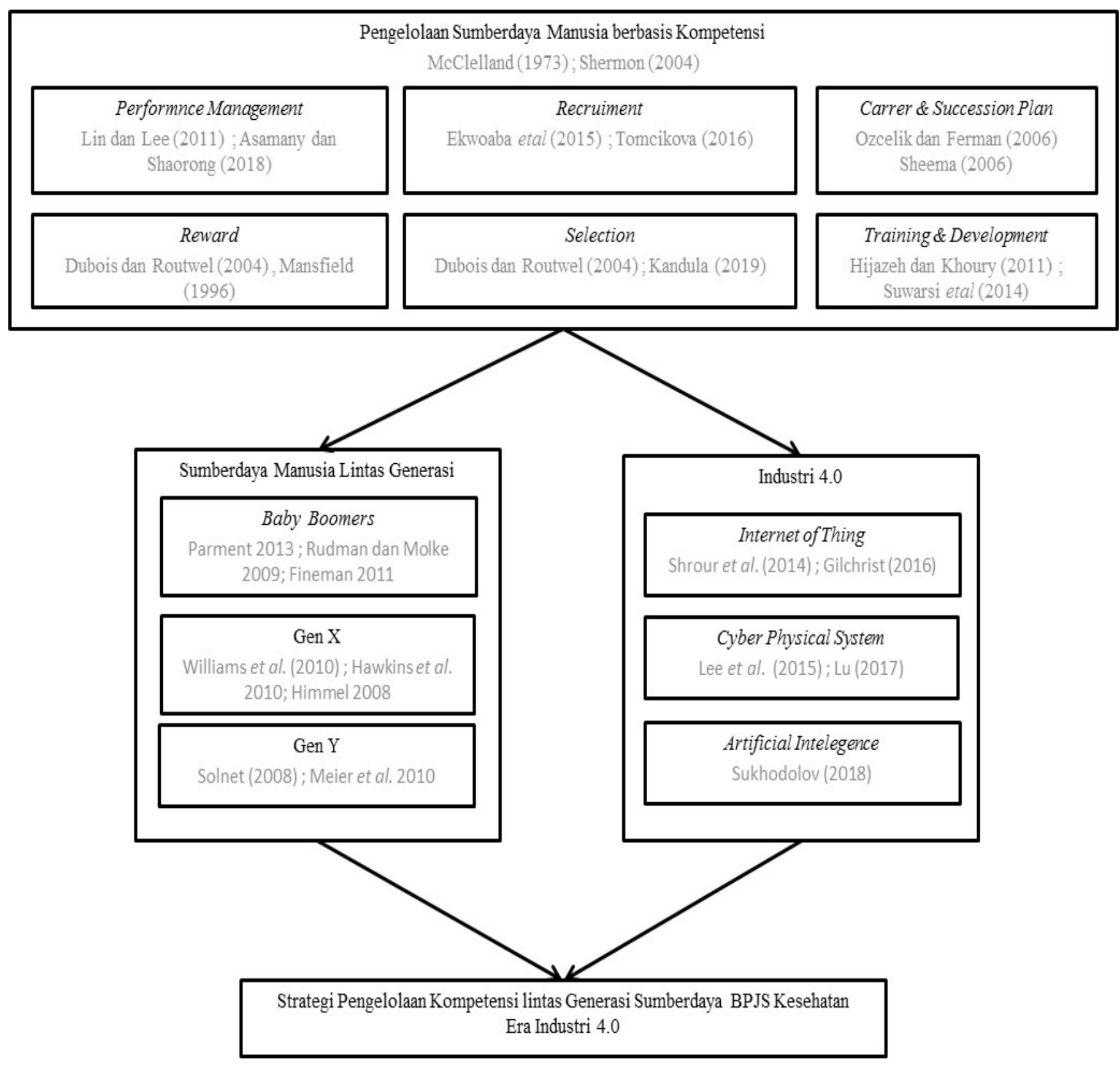

Gambar 1. Kerangka pemikiran penelitian

Proses wawancara dilakukan untuk mendapatkan informasi selain itu sebagai bentukpenyamaan informasi yang didapat satu sumber dengan sumber lainnya. Proses wawancara dilakukan dengan wawancara yang mendalam, sehingga informasi dan keterangan yang dilakukan dapat sesuai dengan harapan dalam rangka menjawabissue. Proseswawancaramendalamdilakukan dengan cara pertemuan (tatap muka) antara peneliti (pewawancara) dengan narasumber (pakar) dengan bantuan kuesioner yang telah disusun sebelumnya. Checkland (1991) menjelaskan bahwa penggunaan soft sytem methodology dilakukan pada tahap identifikasi sistuasi problematik dipandang sebagai real world view, dimana siklus riset mengharuskan peneliti untuk melakukan identifikasi situasi permasalahan pada dunia nyata (A), kemudian dipadu dengan kerangka kerja teori (F) dan metode (M) untuk memformulasikan dan memadu penelitian.

Soft sytem methodology dideskripsikan menjadi sebuah cara untuk mengumpulkan informasi, membuat model serta menetapkan strategi untuk menangani masalah manajemen pada sistem aktifitas manusia atau objek kajian (Martin, 2008). Prasetyaningtyas (2019) menjelaskan bahwa soft sytem methodology mencoba merepresentasikan dan membandingkan dunia nyata dengan dunia model dalam rangka mendapatkan pemahaman yang terbaik dengan cara memberikan 
ide-ide. Daellenbach dan Mcnicke (2005) memberikan penjelaskan bahwa soft sytem methodology memiliki kemampuan untuk memberikan kerangka dalam memahami permasalahan yang dihadapi bahkan pada tingkat yang kompleks. Pelaksanaan dari metode tersebut sudah terbukti dari diterapkannya dalam berbagai kajian seperti pada permasalahan pertanian, energi, sosial dan lingkungan, strategi militer serta model struktural lainnya (Prasetyaningtyas, 2019; Staadt, 2012; Liu et al. 2012; Triyonggo, 2016; dan Riyanto et al. 2014).

Tahapan pada soft system methodology dijelaskan oleh checkhland (1991) terdapat tujuh tahap, setiap tahapnya memiliki fungsi tersendiri. Pada penelitian ini tahap 1) Dilakukan untuk mengidentifikasi permasalahan yang terjadi secara komprehensif dan terstruktur. Pengumpulan informasi dari para stakeholder diperlukan dalam rangka sebagai dasar membuat dan menetapkan strategi pengelolaan sumber daya manusia berbasis kompetensi pada lintas generasi di BPJS Kesehatan. Pada dasarnya stakeholder terdiri dari para pemangku kepentingan seperti dewan direksi yang merupakan pihak internal dan pihak eksternal seperti fasilitas kesehatan kerjasama, regulator, akademisi dan konsultan sumber daya manusia. Tahap 2) dilakukan dengan cara mendeskripsikan situasi dari permasalahan yang terjadi berdasarkan informasi yang didapat pada tahap pertama. Output pada tahap ini adalah membangun rich picture dari representasi keadaan existing yang terjadi pada BPJS Kesehatan. Tahap 3) melakukan pendefinisian terhadap permasalahan yang terjadi. Definisi atau lebih dikenal root definition dilakukan dengan pendekatan suatu sistem melakukan $P$ dengan cara $\mathrm{Q}$ untuk mencapai R. Tahap 4) melakukan penurunan dari root definition menjadi CATWOE (Customer, Actor, Transformation, World view, Owner dan Environment). Proses perubahan tersebut kemudian dibangun model konseptual dalam mencapai tujuan ideal. Seluruh elemen dalam CATWOE dimasukan dalam model konseptual dimana akan dihubungankan melalui garis yang menggambarkan adanya umpan balik atau hubungan antar elemen tersebut. Tahap 5) melakukan perbandingan model yang telah dibuat dari CATWOE dengan model pada dunia nyata. Aktifitas pembandingan dilakukan untuk menyoroti adanya kemungkinan yang harus dipertahankan, diperbaiki ataupun review ulang. Tahap 6) melakukan perubahan yang tepat serta layak dalam mencapai strategi pengelolaan kompetensi lintas generasi terbaik. Output pada tahap ini adalah mendapatkan perubahan yang sesuai, tepat dan layak sehingga mampu berguna bagi organisasi. Tahap 7) dilakukan dengan mengevaluasi dari model yang telah dilakukan. Pada tahap ini rekomendasi atas evaluasi muncul dalam rangka melakukan perubahan pada dunia nyata.

Pada pengembangan kompetensi lintas generasi, karyawan BPJS menjadi objek utama yang dipandang mampu berperan untuk organisasi. Dewan Direksi BPJS Kesehatan berperan untuk menyusun rencana strategis untuk setiap issue dalam rangka mencapai sasaran organisasi, dimana hal ini selalu dikaitkan dengan rancangan pengelolaan kompetensi lintas generasi dalam rangka sustain dan berkembang diera digital saat ini. Akademi memaikan peran dalam menyiapkan tenaga kerja ditahap awal (general) melalui mengajar, membimbing dan mengevaluasi individu. fasilitas kesehatan kerjasama atau rumah sakit atau klinik atau puskesmas memiliki peran untuk melayani pasien (peserta) serta bekerja sama dengan BPJS Kesehatan, dalam kaitan ini sistem antara fasilitas kesehatan kerjasama dan BPJS Kesehatan harus selaras agar integrasi dan sinergi dapat berjalan dengan baik. Regulator memiliki peran sebagai pembuat regulasi untuk mampu mendorong kinerja dari organisasi BPJS Kesehatan dengan organisasi lainnya. Konsultan merupakan bagian diluar yang berperan dalam peningkatan kemampuan dan kompetensi melalui pelatihan, benchmarking, kepakaran dan praktik terbaik organisasi. Adapun matriks pada analisa sosial disajikan pada Tabel 1 .

Managemen diharuskan menyiapkan kompetensi para pegawai yang mampu beradaptasi dengan era digital. Keberhasilan SDM diera digitalisasi harus ditunjang dengan kemampuan dari tiap generasi dalam menjalankan peran-perannya. Generasi yang terlibat saat ini dalam organisasi BPJS Kesehatan adalah generasi baby boomer, generasi $\mathrm{X}$ dan generasi $\mathrm{Y}$ yang diharuskan untuk mampu menjalankan setiap fungsi organisasi. Berdasarkan analisis sosial ditemukan beberapa konflik terkait value, norm dan peran dari tiap aktor, adapun diantaranya: a) Belum optimalnya integrasi perubahan proses bisnis organisasi berbasis digital antara fasilitas kesehatan kerjasama, peserta dengan BPJS Kesehatan. BPJS Kesehatan berupaya menjadi driver perubahan digitalisasi karakteristik industri 4.0 dalam industri kesehatan, hal ini tergambarkan dari adanya aplikasi pelayanan melalui gadget dan sistem administrasi kepesertaan dan klaim yang terintegrasi dengan seluruh fasilitas kesehatan 
kerjasama, tetapi fasilitas kesehatan kerjasama dan peserta maupun pegawai BPJS Kesehatan belum dapat secara optimal beradaptasi dan menerima perubahan yang terjadi; b) Kesenjangan nilai, cara bekerja dan mindset tenaga kerja BPJS Kesehatan dari lintas 3 generasi yang masih belum mampu beradaptasi dan mengetahui kompetensi yang relevan di era digitalisasi; c) Kebijakan pengelolaan SDM dari direksi diharapkan mampu memiliki kemampuan beradaptasi dengan tuntutan teknologi di era industri 4.0. Kepercayaan antara setiap aktor (stakeholder) diperlukan untuk menjamin bahwa setiap sumber daya manusia memberikan kinerja yang terbaik; d) Belum selarasnya Model Kompetensi Sumber Daya Manusia BPJS Kesehatan dengan tantangan era industri 4.0 terhadap praktek praktek terbaik pengelolaan organisasi dan referensi standar kompetensi tenaga kerja industri 4.0. Kondisi tersebut dapat menimbulkan potensi konflik organisasi dalam beradaptasi dengan perubahan sosial dan ekonomi serta teknologi yang terjadi didunia industri.

Berg dan Pooley (2012) memberikan saran bahwa rich picture yang disusun harus mampu memberikan manfaat untuk mengingatkan dan merenungkan suatu masalah. Pengambaran rich picture memang tidak memiliki aturan namun harus informatif dan komunikatif (Checkland dan Scholes, 1991). Kekuatan dari rich picture kemampuan untuk merangkum makna, asosiasi dan komuniasi non verbal (emosi dan perasaan) (Rittel dan Webber, 1984). Lewis (1992) menjelaskan bahwa dalam pengambaran harus berhatihati agar terhindar dari ambiguitas dan salah persepsi.

Pembuatan rich picture menekankan pada hasil wawancara, diskusi dan deep interview. Penggunaan soft sytem methodology dapat digambarkan kedalam suatu bagan yang menunjukan inte-relasi dengan berbagai pihak. Peran yang perlu ada dalam menyusun rich picture yaitu individu atau kelompok yang menyebabkan terjadinya investigasi, dilaksanakannya intervensi (klien), individu atau kelompok yang melakukan investigasi (praktisi) dan pemiliki isu. Rich picture yang disusun harus mampu mengambarkan serta menunjukan peta permasalahan, relasi antar aktor dan pandangan-pandangan yang terkait dalam situasi problematik. Adapun rich picture dalam penelitian pada Gambar 2.

Rich picture yang disusun mengacu pada analisis situasional melalui wawancara mendalam dan focus group discussion dengan para pemangku yang berperan dalam pengelolaan kompetensi lintas generasi karyawan BPJS Kesehatan. Berdasarkan gambar rich picture terdapat dua bagian penting yang mampu mempengaruhi pengelolaan kompetensi lintas generasi di BPJS Kesehatan yaitu antara lain: Stakeholder Internal (bagian yang terdiri dari dewan direksi dan karyawan BPJS Kesehatan. Pengelolaan kompetensi dari setiap karyawan dapat mempengaruhi kinerja organisasi dimasa depan. Permasalahan dalam bagian ini terdapat antara pemimpin, karyawan, karakter yang perlu ada serta dipertahankan dan hubungan dengan stakeholder eksternal) dan Stakeholder Eksternal (bagian yang terdiri dari akademisi, fasilitas kesehatan kerjasama, konsultan dan regulator. Permasalahan yang terjadi hubungan jangka panjang dalam menghadapi issue dunia kesehatan dan kompetensi pegawai menghadapi digitalisasi).

Tabel 1. Analisis sosial dari setiap aktor

\begin{tabular}{|c|c|c|c|}
\hline Aktor & Value & Norm & Peran \\
\hline Dewan Direksi & $\begin{array}{l}\text { Orientasi pada pelayanan } \\
\text { dan bisnis dan pertumbuhan }\end{array}$ & $\begin{array}{l}\text { Kode etik, Peraturan } \\
\text { pemerintah, Peraturan } \\
\text { perusahaan }\end{array}$ & $\begin{array}{l}\text { Menyusun rencana strategis, } \\
\text { Menyelenggarakan dan } \\
\text { mengelola operasional Badan }\end{array}$ \\
\hline Akademisi & $\begin{array}{l}\text { Profesionalisme dan } \\
\text { kejujuran }\end{array}$ & $\begin{array}{l}\text { Kode etik, Peraturan } \\
\text { pemerintah }\end{array}$ & $\begin{array}{l}\text { Mengajar, membimbing Calon } \\
\text { tenaga kerja dan mengevaluasi } \\
\text { sistem pendidikan }\end{array}$ \\
\hline $\begin{array}{l}\text { Fasilitas kesehatan } \\
\text { kerjasama }\end{array}$ & $\begin{array}{l}\text { Orientasi pada pelayanan } \\
\text { dan bisnis serta pertumbuhan }\end{array}$ & $\begin{array}{l}\text { Kode etik, Peraturan } \\
\text { pemerintah, Perjanjian } \\
\text { kerjasama }\end{array}$ & $\begin{array}{l}\text { Melayani pasien Peserta BPJS } \\
\text { Kesehatan, melakukan kerjasama }\end{array}$ \\
\hline Regulator & $\begin{array}{l}\text { Profesionalisme dan } \\
\text { transparan }\end{array}$ & Peraturan pemerintah & $\begin{array}{l}\text { Membuat aturan, kebijakan dan } \\
\text { mekanisme }\end{array}$ \\
\hline $\begin{array}{l}\text { Praktisi Sumber Daya } \\
\text { Manusia }\end{array}$ & $\begin{array}{l}\text { Profesionalisme dan } \\
\text { integritas }\end{array}$ & $\begin{array}{l}\text { Kode etik, Peraturan } \\
\text { perusahaan }\end{array}$ & $\begin{array}{l}\text { Memberikan masukan,Best } \\
\text { Practice dan pelatihan serta } \\
\text { informasi issue terkini }\end{array}$ \\
\hline
\end{tabular}




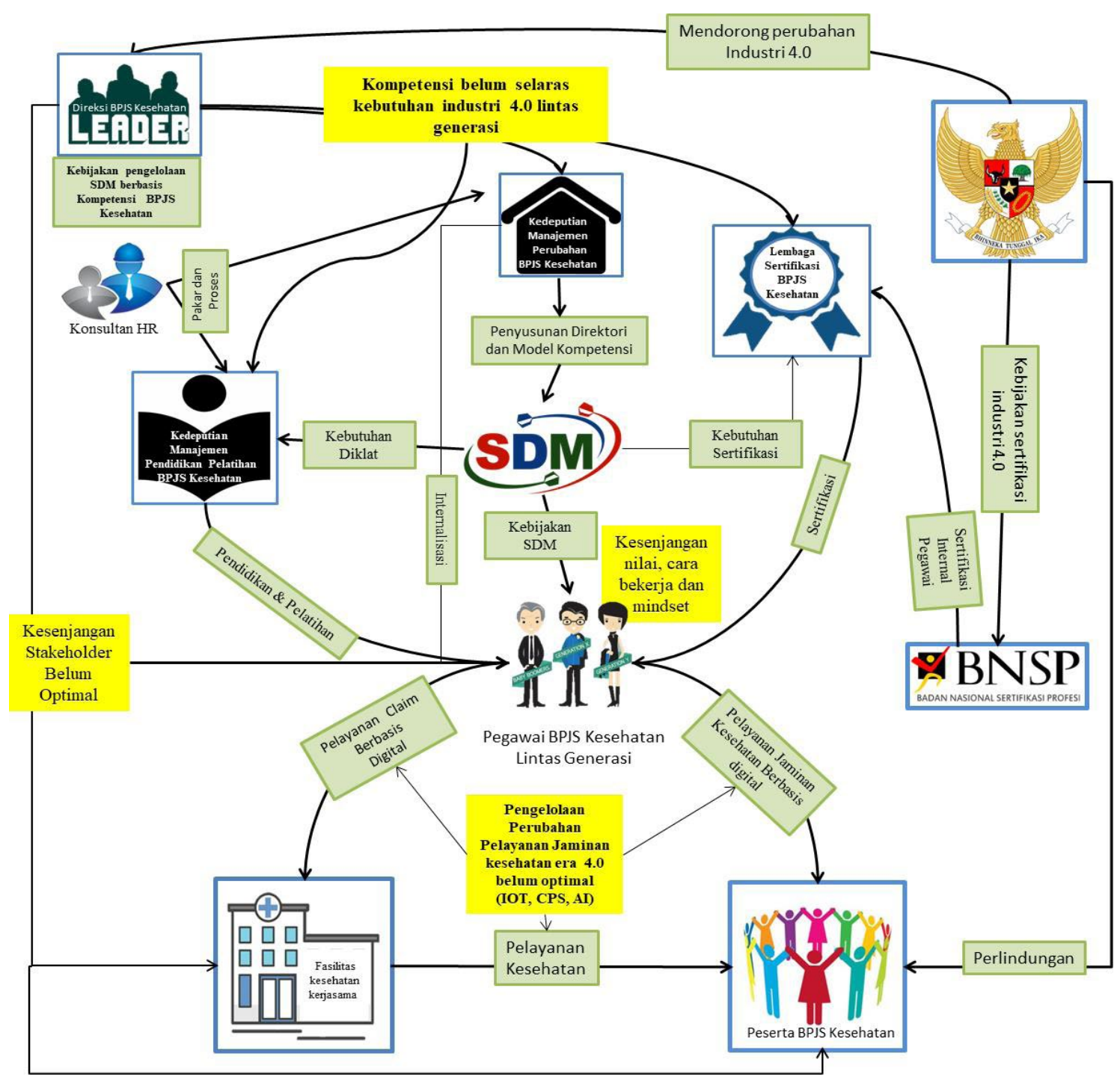

Gambar 2. Rich Picture

Pegawai harus mampu menjadi bagian yang terintegrasi dalam pengelolaan perubahan organisasi untuk melakukan sinergi dengan fasilitas kesehatan kerjasama dan peserta dalam rangka bersama-sama mempercepat mencapai industri kesehatan yang adaptif terhadap tantangan industri 4.0. Pada rich picture ditemukan bahwa tiap generasi memiliki perbedaan cara kerja, mindset kerja serta value yang perlu dimanfaatkan diera industri 4.0. Adapun pembahasan dijabarkan pada Tabel 2.

Konsep dasar terjadinya perbedaan generasi adalah ketika sekelompok individu secara luas terpengaruhi oleh kejadian, fenomena sejarah dan atau budaya dalam fase kehidupannya sehingga berdampak pada adanya perbedaan perilaku, nilai dan kepribadiaan (Noble dan Schewe, 2003; Caspi et al. 2005 ; Kristanto et al. 2017). Perbedaaan ini dapat terjadi akibat perbedaan perkembangan psikososial, Erikson (1963) telah menjelaskan mengenai perkembangan manusia dalam delapan tahap (kepercayaan-kecurigaan, otonomi-perasaan malu, inisiatif-kesalahan, kerajinaninferioritas, identitas-kekacauan identitas, keintimanisolasi, generative-stagnasi, integritas-keputusaaan).

Perkembangan psikologi sangat terkait dengan pemberdayaan psikologi, dimana setiap manusia mengalami empat proses kognisi yaitu meaning, competence, self determination dan impact (Spreizer, 1995). Hal ini menandakan bahwa setiap generasi pasti mengalami proses tersebut. Josef dan Soeharso (2009) telah menjelaskan bahwa tujuan dari pemberdayaan psikologis agar sumberdaya manusia memiliki kemampuan serta tanggung jawab yang jelas dalam pelaksanaan misi. Hal ini menjelaskan bahwa pemberdayaan psikologis akann berdampak pada pencapaian kinerja yang diharapkan. Pemberdayaan psikologi dari tiap generasi sangat dipengaruhi oleh 
perkembangan industri dan teknologi, dimana sebelum industri 4.0 terjadi gap antara masyarakat disuatu daerah dengan daerah lainnya. Kondisi berbeda ketika industri 4.0 serta globalisasi terjadi diseluruh dunia, dimana dapat dikatakan tidak ada gap. Temuan ini menunjukan bahwa selanjutnya perkembangan psikologi dari generasi bila ditinjau dari kacamata industri dan teknologi akan memiliki suatu kesamaan.

Pada organisasi diketahui bahwa psikologi seseorang dapat dipengaruhi oleh adanya peran dari pihak lain, dalam hal pemimpin. Prabowo et al. (2018) menjelaskan bahwa kepemimpinan mampu mempengaruhi psikologi dari pekerja, dimana hal ini tergambarkan aktifitas dan perilaku kerja yang lebih baik. Keberhasilan tersebut harus ada dasar dimana anggota organisasi (pegawai) mampu mempercayai pemimpin serta pemimpin mampu menjadi sosok yang dipercaya. Rantika dan Yustina (2017); Chugtai et al. (2015) menjelaskan mengenai konsep kepercayaan menjadi dasar pemimpin yang mampu mempengaruhi anggotanya disemua kasus yang terjadi dalam organisasi, dimana kepercayaan menjadi bagian yang memediasi seluruh perubahan yang terjadi.

Konstruksi dari root definition terhadap situasi dunia nyata yang problematik menjadi dasar untuk membentuk model konseptual dari sistem aktifitas yang memiliki tujuan. Kehandalan dari sistem yang telah didefinisikan dalam bentuk root definition kemudian diuji menggunakan CATWOE perlu dilanjutkan dengan menentukan kriteria pengukuran kinerja, adapun kriteria ini dengan nama 5Es yaitu efficacy yang menggambarkan mengenai transformasi yang dilaksankan benar-benar dapat berlangsung dan mendapatkan hasil yang diinginkan; efficiency menjelaskan bahwa transformasi yang dilaksanakan menggunakan sumber daya yang minimal; effectiveness menyatakan bahwa transformasi akan membantu pencapaian tujuan yang lebih tinggi atau lebih panjang, Elegance mengukur proses transformasi yang dilakukan berlangsung dengan cantik atau elegan. Ethicality mengukur proses transformasi yang dipraktekkan mendapatkan pembenaran secara moral (Checkland dan Scholes, 1990). Root definition dari problematik yang terjadi dalam penelitian ini didasarkan dari penjabaran wawancara yang dilakukan dengan responden. Adapun root definition berdasarkan penelitian ini sebagai berikut :

\section{"Sistem pengelolaan sumber daya manusia berbasis kompetensi BPJS Kesehatan melalui pengelolaan perubahan internal (lintas generasi) dan eksternal (IOT, CPS dan AI) (P) organisasi secara terukur dan berkelanjutan (Q) untuk mencapai visi misi organisasi di era industri 4.0 (R)"}

Definisi yang didapat untuk kajian pengelolaan kompetensi lintas generasi di BPJS Kesehatan, kemudian akan dijadikan dasar dalam alat intelektual untuk melakukan diskusi serta dialog untuk menemukan rancang bangun sistem pengelolaan kompetensi lintas generasi yang lebih baik. Sistem pengelolaan kompetensi harus mampu diterima oleh semua pihak (generasi) yang terlibat dalam organisasi, sebagai bentuk dari pengedepanan aspek objektifitas. Definisi yang didapat kemudian dilakukan pengujian dengan mengunakan analisis CATWOE disajikan pada Tabel 3.

Tabel 2. Matrik perbedaan cara kerja, mindset dan value ditiga generasi

\begin{tabular}{llll}
\hline Uraian & Cara Kerja & Mindset & Values \\
\hline Generasi BB & Pekerja keras & Orientasi pada pengakuan & Kesetiaan \\
Generasi X & Ketekunan dalam bekerja & Transparansi & Inovatif \\
Generasi Y & Multi tasking & Keseimbangan & Kreatifitas \\
Kebutuhan Generasi & Persistensi, dengan & Transparansi dan fairness & Kesepahaman nilai atas luasnya \\
& pendekatan multidisiplin dan & atas apresiasi setiap & potensi kreativitas dan inovasi \\
& tidak mudah menyerah & pencapaian & yang timbul
\end{tabular}


Tabel 3. CATWOE pengelolaan kompetensi lintas generasi BPJS Kesehatan Industri 4.0

\begin{tabular}{|c|c|c|}
\hline Elemen & Identifikasi & Hasil \\
\hline Customer & $\begin{array}{l}\text { Siapa yang diuntungkan } \\
\text { dengan adanya perubahan? }\end{array}$ & $\begin{array}{l}\text { Pegawai BPJS Kesehatan, Fasilitas kesehatan kerjasama, } \\
\text { Pemerintah dan Peserta }\end{array}$ \\
\hline Actor & $\begin{array}{l}\text { Siapa yang terlibat dalam } \\
\text { proses perubahan? }\end{array}$ & $\begin{array}{l}\text { Board of Directors (BOD), Pegawai BPJS Kesehatan, Fasilitas } \\
\text { kesehatan kerjasama, peserta dan pemerintah }\end{array}$ \\
\hline Transformation & $\begin{array}{l}\text { Perubahan apa yang } \\
\text { diinginkan terjadi di dalam } \\
\text { sistem? }\end{array}$ & $\begin{array}{l}\text { Pengelolaan SDM yang belum berbasis kompetensi era industri } \\
4.0 \text { lintas generasi menjadi pengelolaan berbasis kompetensi era } \\
\text { industri } 4.0 \text { lintas generasi. }\end{array}$ \\
\hline World view & $\begin{array}{l}\text { Apa gambaran besar dari } \\
\text { perubahan yang diharapkan? } \\
\text { Dampak luas dari issue } \\
\text { tersebut? }\end{array}$ & $\begin{array}{l}\text { Sinergi antara seluruh pemangku kepentingan dalam merespon } \\
\text { perubahan industri } 4.0 \text { dan karakteristik lintas generasi akan } \\
\text { mencapai visi misi organisasi BPJS Kesehatan dan reputasi serta } \\
\text { kredibilitas sistem jaminan kesehatan nasional di mata dunia. }\end{array}$ \\
\hline Owner & $\begin{array}{l}\text { Siapa pemilik dari isu yang } \\
\text { sedang diteliti? }\end{array}$ & Board of Directors (BOD) \\
\hline Environment & $\begin{array}{l}\text { Apa saja faktor yang bisa } \\
\text { mempengaruhi solusi dari } \\
\text { permasalahan yang sedang } \\
\text { diteliti? }\end{array}$ & $\begin{array}{l}\text { Value, Mindset, Comunication, Leadership, external trust, } \\
\text { policy. }\end{array}$ \\
\hline
\end{tabular}

Tabel 4. Pengukuran kinerja pengelolaan kompetensi lintas Generasi BPJS Kesehatan Industri 4.0

\begin{tabular}{|c|c|}
\hline Elemen & Keterangan \\
\hline Efficacy & $\begin{array}{l}\text { Terselengaranya pengelolaan sumber daya manusia berbasis kompetensi era industri } 4.0 \text { lintas generasi di } \\
\text { BPJS Kesehatan }\end{array}$ \\
\hline Efficiency & Proses perubahan terlaksana dengan sumber daya finansial, waktu dan tenaga kerja yang optimal. \\
\hline Effectiveness & $\begin{array}{l}\text { Tercapainya indeks ketercapaian kompetensi era industri } 4.0 \text { di BPJS Kesehatan dan mencapai tujuan } \\
\text { organisasi BPJS Kesehatan. }\end{array}$ \\
\hline Elegance & $\begin{array}{l}\text { Tercapainya indeks resistensi perubahan pada pegawai BPJS Kesehatan, fasilitas kesehatan kerjasama, } \\
\text { peserta dan Regulator. }\end{array}$ \\
\hline Ethicality & $\begin{array}{l}\text { Proses perubahan pengelolaan sumber daya manusia dapat diterima secara moral dan etis oleh pemangku } \\
\text { kepentingan. }\end{array}$ \\
\hline
\end{tabular}

Pengelolaan kompetensi dijadikan dasar dalam mensinergikan setiap pemangku kepentingan di industri kesehatan agar siap memberikan respon terbaik diindustri 4.0. Pemiliki issue dalam pengelolaan adalah para pemimpin BPJS Kesehatan khususnya board of director. Pengukuran kinerja dari CATWOE yang telah disusun diperlukan sebagai dasar dalam mengetahui ketepatan, susunan kinerja tergambarkan pada Tabel 4.

Berdasarkan Tabel 4 didapatkan informasi bahwa terdapat lima ukuran dalam mencapai pengelolaan sumber daya manusia berbasis kompetensi era industri era industri 4.0 lintas generasi di BPJS Kesehatan. Proses perubahan harus sesuai dengan kebutuhan sumber daya finansial, waktu dan tenaga kerja yang optimal. Tercapainya indeks ketercapaian kompetensi era industri 4.0. Tercapainya indeks resistensi perubahan pada pegawai BPJS Kesehatan, fasilitas kesehatan kerjasama, peserta dan regulator. Proses perubahan pengelolaan sumber daya manusia dapat diterima secara moral dan etis oleh pemangku kepentingan.

Model konseptual harus bersifat relevan dengan situasi dan bukan model yang mewakili, namun berkaitan dengan apa yang harus dilakukan oleh sistem (Fitriati, 2014). Penyusunan model konseptual memiliki beberapa pedoman penting yang dijelaskan oleh Fitriati (2014), yaitu 1) Model konseptual harus dikonstruksi berdasarkan kata-kata yang terdapat pada root definition tanpa mengaitkan kembali dengan situasi. Memasukan sejumlah aktifitas atau kelompok kegiatan didalam model konseptual harus didukung oleh kata-kata atau frase didalam root definition. 2) Peneliti harus menggunakan kata-kata yang dapat menggambarkan kegiatan dalam proses transformasi yang dijelaskan secara tepat. Konsep ini berkaitan dengan penjelasan bahwa kegiatan didalam model konseptual dapat menjadi sumber perkembangan root definition untuk analisis sistem yang relevan dan model 
konseptual yang lebih terperinci. 3) Model konseptual harus dapat dipertanggung jawabkan.

\section{Penerapan Model Pengelolaan Sumber Daya Manusia Berbasis Kompetensi Era Industri 4.0}

Direksi menginisiasi perubahan pengelolaan SDM dalam organisasi, dimana saat ini organisasi melihat secara komprehensif kondisi internal dan eksternal. Hal ini dipandang penting karena ditemukan adanya benturan cara kerja, mindset dan value dari 3 generasi yang menjadi pendukung kinerja organisasi. Tiga generasi tersebut harus dikelola dengan baik dalam rangka mengeluarkan seluruh kemampuan yang dimiliki, hal ini dapat dilakukan dengan cara pendekatan menerapkan pengelolaan perubahan. Pengelolaan eksternal dipandang penting akibat adanya tuntutan dari era industri 4.0, yang mengharuskan organisasi untuk mengikuti perubahan. Hal yang dapat dilakukan oleh perusahaan adalah menyelaraskan kapasitas internal dan merespon kebutuhan perubahan lingkungan eksternal tersebut. Dalam pengelolaan internal dan ekstenal dapat menerapkan prinsip-prinsip dari Kotter terkait dengan 8 langkah manajemen perubahan, yaitu 1) menciptakan sense of urgency 2) Menciptakan koalisi kepemimpinan yang kuat 3) Memiliki visi untuk perubahan 4) Menyingkirkan hambatan dalam proses 4) Mengkomunikasikan visi dengan jelas 5) Menyingkirkan hambatan dalam proses 6) Merencanakan dan menciptakan kemenangan jangka pendek secara sistematis 7) Menguatkan perubahan dan 8) Menanamkan pengelolaan perubahan sebagai budaya organisasi.

Pengelolaan sumberdaya manusia dapat dimulai dari mengoptimalkan fungsi kepemimpinan dan manajerial yang berfokus pada cara kerja, mindset kerja dan value. Akulturasi cara kerja, mindset dan value dari ketiga generasi yang tergambarkan dari terbentuknya cara kerja yang tekun (persistensi) dengan pendekatan multidisiplin dan tidak mudah menyerah, kemudian dari mindset yang dibangun terbentuknya transparansi dan fairness atas apresiasi setiap pencapaian, sedangkan dari sisi value adanya kesepahaman nilai atas luasnya potensi ruang kreativitas dan inovasi yang timbul. Pada akhirnya kondisi ini akan mendorong untuk menginternalisasi budaya era industri 4.0 pada sumberdaya manusia diorganisasi yang diwujudkan dalam bentuk kompetensi organisasi dan kompetensi individu yang direfleksikan dalam kebijakan sumberdaya manusia era industri 4.0 di organisasi.
Lingkungan eksternal (provider, peserta dan organisasi/ lembaga) menjadi bagian yang perlu dikelola dalam rangka mewujudkan tenaga kerja yang menjadi bagian pendorong organisasi yang maju. Hal ini dapat dilakukan dengan melakukan komunikasi terbuka, mengajak serta membuat ukuran perubahan yang efektif dan diharapkan oleh manajemen terhadap lingkungan eksternal seperti provider, peserta bahkan organisasi/ lembaga yang berinteraksi. Pada sisi internal organisasi manajemen dapat mengukur dengan pendekatan tingkat retention pegawai untuk tetap bertahan di organisasi BPJS Kesehatan dan untuk sisi eksternal manajemen dapat membuat ukuran yang sistematis dengan pendekatan 5Es. Hal ini ditujukan agar aktifitas perubahan yang dilakukan dapat dievaluasi secara berkala perkembangan dari waktu kewaktu, adapun 5Es tersebut yaitu 1) Efficacy 2) Efficency 3) Effectiveness 4) Elegance 5) Ethicality.

\section{KESIMPULAN DAN SARAN}

\section{Kesimpulan}

Pada pengelolaan sumberdaya manusia berbasis kompetensi yang ada saat ini ditemukan beberapa kesenjangan; a) Pengelolaan kompetensi yang belum selaras dengan kebutuhan industri 4.0, dimana tergambarkan direktori dan model kompetensi yang dimiliki masing sangat distinctive pada fungsi tertentu. b) Adanya kesenjangan kepercayaan stakeholder belum optimal yang terlihat dari pandangan stakeholder diruang publik. c) Kesenjangan nilai, cara bekerja serta mindset pada pegawai dimana terlihat dari masih adanya benturan persepsi dalam interaksi kerja. d) Pengelolaan perubahan industri 4.0 (internet of thing, cyber physical sytem dan artificial intelegence) pelayanan jaminan kesehatan belum optimal, hal ini tergambarkan dari aktifitas pengelolaan perubahan yang masih fokus terhadap sisi internal organisasi saja namun belum sistematis kearah eksternal organisasi. Model Pengelolaan sumberdaya manusia berbasis kompetensi lintas generasi era 4.0 memberikan langkah-langkah strategik yang dilakukan dalam mengelola sumberdaya manusia BPJS kesehatan berbasis kompetensi terkait lintas generasi dan industri 4.0 dengan membangun karakteristik kepemimpinan dan managerial yang dapat diterima di semua generasi di era industri 4.0 sehingga organisasi dapat mencapai tata kelola yang baik dan menciptakan kepercayaan di internal dan eksternal organisasi. 


\section{Saran}

Saran yang dapat dilakukan dalam penelitian antara lain: 1) Direksi BPJS Kesehatan menjadikan Model dan Strategi Pengelolaan Sumberdaya Manusia Lintas Generasi era Industri 4.0 menjadi masukan kebijakan dan implementasi pengelolaan sumberdaya manusia berbasis kompetensi sebagai bagian dalam dokumen rencana strategis (Renstra) jangka panjang organisasi BPJS Kesehatan. 2) BPJS Kesehatan menyiapkan instrumen penilaian eksternal dengan pendekatan 5 Es. Ukuran tersebut dapat dijadikan untuk tmengimplementasikan perencanaan pengelolaan perubahan organisasi dengan menjadikan sebagai key result Indicator (KRI) organisasi dan menjadi key performance indicator (KPI) individu di unit kerja. Hal ini ditujukan untuk mencapai pengelolaan perubahan yang terukur dan berkelanjutan di Industri jaminan kesehatan Indonesia. Harapannya dari aktifitas tersebut mampu menciptakan kepercayaan eksternal dan meretensi pegawai unggul organisasi BPJS Kesehatan.

\section{DAFTAR PUSTAKA}

Al-Azzeh DY, Nuaimi MA. 2015. CompetencyBased Human Resources Management and Organizational Performance: Riyadh Bank Case Study [Tesis]. Amman: Middle East University. Ashkezari MJD, Aeen MN. 2012. Using Competency Models to Improve HRM. Conference Prosiding

Berg T, Pooley R 2012. Rich Pictures: A valuable means to explore complex IS . issues UK Academy for Information Systems Conference Proceedings 2012. Paper 1.

Bosch OJH, King CA, Herbohn JL, Russell IW, Smith CS. 2007. Getting the big picture in natural resource management - systems thinking as 'method' for scientists, policy makers and other stakeholders. Systems Research and Behavioral Science 24(1): 217-232.

Caspi A, Robert BW, Shiner RL. 2005. Personality development: stability and change. Annual review psychology 56(1):453-84.

Caspi A, Robert BW. 2001. Personality Development Across the Life Course:The Argument for Change and Continuity. Psycological Inquiry 12(2):49-66.

Checkland P, Poulter J. 2006.Learning for Action. England: John Wiley \& Sons Ltd.

Checkland P, Scholes. 1991. Soft Systems Methodology in Action. Chichester: Wiley.

Checkland P. 1991. Soft Systems Methodology. Chichester: Wiley.

Chughtai AM. Byrne, Flood B. 2015. Linking ethical leadership to employee well-being: the role of trust in supervisors. Journal of business ethics. 128(3): 653-663.

Daellenbach HG, McNickle DC. 2005. Management Science: Decision Making Through Systems Thinking. Palgrave Macmillan: Hampshire.

Davis M, Girou M. 1996. Integrating soft systems and object-oriented analysis. Proceedings of International Conference on Requirements Engineering. 15-18.

Deloitte. 2018. Transforming the Future of Manufacturing: Technology, Talent, and The Innovation Ecosystem. New York: Deloitte university press.

Dencker J, Joshi A, Martocchio. 2008. Towards a theoretical framework linking generational memories to attitudes and behaviours. Human Resourse Management Review 18(2) : 180-187

Erikson EH. 1963. Childhood society. Newyork: Norton.

Fitriati R. 2015. Menguak daya saing UMKM industri kreatif: Sebuah riset tindakan berbasis Soft System Methodolgy. Jakarta: Yayasan Pustaka Obor.

Josef P, Soeharso SSY. 2009. Pengaruh Kepemimpinan Transformasional dan Pemberdayaan Psikologis terhadap Pembentukan Komitmen Organisasional [Tesis]. Jakarta: Universitas Katolik Indonesia Atmajaya.

Kavanagh MJ, Thite M, Johnson RD. 2015. Human resource information systems. Thousand Oaks: Sage.

Khannad VK, Gupta R. 2014. Comparative study of the impact of competency-based training on 5 "s" and tqm: a case study. International journal of quality \& reliability management 31(3): 238260.

Kristanto YD, Fahmi I, Maulana A. 2017. Pengembangan kamus kompetensi keselamatan kerja di pt xyz indonesia tbk. Jurnal Aplikasi Bisnis Dan Manajemen (JABM) 3(1): 1-11.

Lewis. 1992. Rich picture building in the soft systems methodology. European journal of information systems $1(5): 351-360$.

Liu WB, Meng W, Mingers J, Tang N, Wang W. 2012. Developing a performance management system using soft systems methodology: a Chinese 
case study. European Journal of Operational Research 223(2): 529-540.

Martin E. 2008. Aplikasi metodologi system lunak untuk pengelolaan Kawasan hutan rawan konflik: kasus hutan penelitian benakat Sumatra selatan [Tesis]. Bogor : Institut Pertanian Bogor

Noble SM, Schewe CD. 2003. Cohort segment An exploration of its validity. Journal of Business Research 56(12): 979-989.

Ozcelik G, Ferman M. 2006. Competency Approach to Human Resources Management: Outcomes and Contributions in a Turkish Cultural Context. Human Resource Development Review 5(1): 7291.

Prabowo R, Mustika MD, Sjabahnyi B. 2018. How a Leader Transforms Employees' Psychological Empowerment into Innovative Work Behavior. Psychological Research on Urban Society 1(2): 90-99.

Prasetyaningtyas SW. 2019. Strategi keberlanjutan bisnis pertanian hortikultura organic di Indonesia [Disertasi]. Bogor: Institut Pertanian Bogor.

Qiao JX, Wang W.2009. Managerial competencies for middle managers: some empirical findings from China. Journal of european industrial training. 33(1): 69-80.

Rantika SD, Yustina AI. 2017. Effects of ethical leadership on employee well-being: the mediating role of psychological empowerment. Journal of indonesia economy and business 32(2): 121-137.

Rittel H, Webber M. 1984. Planning Problems are Wicked problems. (N.cross, Ed.) Chichester: Wiley \& Sons.

Riyanto A, Eriyatno, Pasaribu B, Maulana A. 2014. Model of outsourcing policy institutional integration in inudtrial relation perspective using soft sytem methodology: case study in Bekasi regency Indonesia. International journal of information technology and business management 18(1): 24-34.

Rosyadi S. 2018. Revolusi Industri 4.0: Peluang dan Tantangan Bagi Alumni Universitas Terbuka. https://www.researchgate.net/profile/ Slamet_Rosyadi/publication/324220813 R E V O L U S I_ I N D U S T R I _ $40 /$ links/5ac5d7eb0f7e9b1067d4e1ba/REVOLUSIINDUSTRI-40.

Sarantopoulos. 2017. Establishing face validity of the eplit questionnaire. British Journal of Healthcare Management 23(5): 1-12.

Spreitzar GM. 1995. Psycological empowerment in the workplace: dimnssions, measurement, and validation. Academy of Management Journal 38(5): 1442-1456

Staadt J. 2012. Redesigning a project-oriented organization in a complex system: a soft systems methodology approach. International Journal of Managing Projects in Business 5(1): 51-66.

Stone DL, Deadrick DL. 2015. Challenges and opportunities affecting the future of human resource management. Human Resource Management Review 25 (2) 139-145.

Triyonggo Y. 2016. Rancang bangun model pengembangan kompetensi profesi manajemen sumberdaya manusia di Indonesia [Disertasi]. Bogor: Institut Pertanian Bogor.

William B. 2005. Soft System Methodology. The Kellogg Foundation. Users.

Zarei B, Azizian S, Ghapanchi AH. 2013. Road freight information systems: a soft system methodology approach. International Journal Logistic Systems and Management 14(2): 161-174. 